\title{
Blue Light-emitting Diode Light Irradiation of Seedlings Improves Seedling Quality and Growth after Transplanting in Red Leaf Lettuce
}

\author{
Masahumi Johkan, Kazuhiro Shoji ${ }^{1}$, Fumiyuki Goto, \\ Shin-nosuke Hashida, and Toshihiro Yoshihara \\ Central Research Institute of Electric Power Industry, Abiko, Chiba 270- \\ 1194, Japan
}

Additional index words. anthocyanin, antioxidant activity, biomass, photosynthetic pigment, polyphenol

\begin{abstract}
In this study, we determined the effects of raising seedlings with different light spectra such as with blue, red, and blue + red light-emitting diode (LED) lights on seedling quality and yield of red leaf lettuce plants. The light treatments we used were applied for a period of 1 week and consisted of $100 \mu \mathrm{mol} \cdot \mathrm{m}^{-2} \cdot \mathrm{s}^{-1}$ of blue light, simultaneous irradiation with $50 \mu \mathrm{mol} \cdot \mathrm{m}^{-2} \cdot \mathrm{s}^{-1}$ of blue light and $50 \mu \mathrm{mol} \cdot \mathrm{m}^{-2} \cdot \mathrm{s}^{-1}$ of red light, and $100 \mu \mathrm{mol} \cdot \mathrm{m}^{-2} \cdot \mathrm{s}^{-1}$ of red light. At the end of the light treatment, that is $\mathbf{1 7}$ days after sowing (DAS), the leaf area and shoot fresh weight (FW) of the lettuce seedlings treated with red light increased by $33 \%$ and $25 \%$, respectively, and the dry weight of the shoots and roots of the lettuce seedlings treated with blue-containing LED lights increased by greater than $29 \%$ and greater than $\mathbf{8 3} \%$ compared with seedlings grown under a white fluorescent lamp (FL). The shoot/root ratio and specific leaf area of plants irradiated with blue-containing LED lights decreased. At 45 DAS, higher leaf areas and FWs were obtained in lettuce plants treated with blue-containing LED lights. The total chlorophyll (Chl) contents in lettuce plants treated with blue-containing and red lights were less than that of lettuce plants treated with FL, but the $\mathrm{Chl} a / b$ ratio and carotenoid content increased under blue-containing LED lights. Polyphenol contents and the total antioxidant status (TAS) were greater in lettuce seedlings treated with blue-containing LED lights than in those treated with FL at 17 DAS. The higher polyphenol contents and TAS in lettuce seedlings at 17 DAS decreased in lettuce plants at 45 DAS. In conclusion, our results indicate that raising seedlings treated with blue light promoted the growth of lettuce plants after transplanting. This is likely because of high shoot and root biomasses, a high content of photosynthetic pigments, and high antioxidant activities in the lettuce seedlings before transplanting. The compact morphology of lettuce seedlings treated with blue LED light would be also useful for transplanting.
\end{abstract}

In modern agriculture, the raising of seedlings and the cultivation of crops are often separated. Because seedlings are raised in small areas, farmland is efficiently used. Moreover, control over seedling growth such as achieving high rates of germination and uniformity in seedling morphology is easy to manage in plant nurseries, allowing seedlings of high quality to be raised.

The quality of seedlings affects their growth and yield after transplantation. Goodquality seedlings exhibit morphological characteristics such as thick stems, thick leaves, dark green leaves, and large white roots (Oda,

\footnotetext{
Received for publication 24 June 2010. Accepted for publication 4 Oct. 2010.

This work was supported by a grant for "Elucidation of biological mechanisms of photoresponse and development of advanced technologies utilizing light."

We thank Ms. Mina Ozaki and Ms. Noriko Nikaido for technical assistance.

${ }^{1}$ To whom reprint requests should be addressed; e-mailshoji@criepi.denken.or.jp.
}

2007). Seedlings with elongated stems, thin leaves, light green leaves, and small undeveloped roots are weak and subject to environmental stress (Seiler and Johnson, 1988). This results in decreased yield. Therefore, raising high-quality seedlings is important for increasing the yield of crops.

Plant development and physiology are strongly influenced by the light spectrum, which affects the seedling morphology pattern (McNellis and Deng, 1995). For example, blue light suppresses hypocotyl elongation and induces cotyledon expansion, and red light induces hypocotyl elongation and cotyledon expansion in Arabidopsis seedlings. Blue light is involved in a wide range of plant processes such as phototropism, photomorphogenesis, stomatal opening, and photosynthesis (Whitelam and Halliday, 2007). Most studies with blue light only or blue mixed with red light indicated that blue light-containing irradiation produced higher plant biomass (Matsuda et al., 2008; Yorio et al., 2001). Hanyu and Shoji (2002) suggested that yield and crop quality could be improved by controlling light quality. However, application of the blue spectrum when raising seedlings has rarely been studied.

The light spectrum also stimulates the biosynthesis of phenolic compounds. Blue light induced the accumulation of flavonoids (Ebisawa et al., 2008; Kojima et al., 2010) and anthocyanins, which are one class of flavonoid compounds, play a role in antioxidant activity (Duan et al., 2007). Moreover, chlorogenic acid, which had higher antioxidant activities than vitamins $\mathrm{C}$ and $\mathrm{E}$ (RiceEvans et al., 1997), was also increased by blue light (Awada et al., 2001). Because better growth of plants under environmental stresses was associated with higher antioxidant activity (Rivero et al., 2003), raising seedlings irradiated with blue light can potentially increase crop yield after planting because of the high accumulation of phenolic compounds.

LED lights create specific wavelengths and a narrow bandwidth for plant growth compared with filters with broad-spectrum light sources. Therefore, blue LED lights can produce the specific blue spectrum more efficiently than blue filters with other light sources. In this study, we determined the effects of raising seedlings with different light spectra such as with blue, red and blue + red LED lights on seedling quality and yield of red leaf lettuce plants. Photosynthetic pigments, polyphenols, and antioxidant activity of lettuce seedlings treated with different light spectra were also determined.

\section{Materials and Methods}

Plant growth. Seeds of red leaf lettuce (Lactuca sativa L. cv. Banchu Red Fire; Takii Seed Co., Kyoto, Japan) were pregerminated for $1 \mathrm{~d}$ at $23 \pm 2{ }^{\circ} \mathrm{C}$ under $100 \mu \mathrm{mol} \cdot \mathrm{m}^{-2} \cdot \mathrm{s}^{-1}$ photosynthetic photon flux $(P P F)$ for $14 \mathrm{~h}$ with a white FL (FLR110H-W1A; Mitsubishi/ Osram Co., Yokohama, Japan). Germinated seeds were sown in a 200 -cell tray $(16 \mathrm{~mL} /$ cell $)$ filled with a mixture of peatmoss (Tanemaki Baido; Takii Seed Co., Kyoto, Japan) and vermiculite (VS Kako Co., Tokyo, Japan) at a ratio of $2: 1(\mathrm{v} / \mathrm{v})$. The lettuce seedlings were grown in the chamber at $23 \pm 2{ }^{\circ} \mathrm{C}$ under $100 \mu \mathrm{mol} \cdot \mathrm{m}^{-2} \cdot \mathrm{s}^{-1} \mathrm{PPF}$ for $14 \mathrm{~h}$ with $\mathrm{FL}$. All lettuce seedlings were placed $45 \mathrm{~cm}$ below the FL. At 10 DAS, the lettuce seedlings were either placed $45 \mathrm{~cm}$ below the FL or $20 \mathrm{~cm}$ below the blue (peak wavelength: $468 \mathrm{~nm}$, bandwidth at half peak height: $21 \mathrm{~nm}$ ), red $(660 \mathrm{~nm}, 22 \mathrm{~nm})$, or blue + red [ $467+655 \mathrm{~nm}$, $21+20 \mathrm{~nm}$; blue/red light density $(P P F)$ ratio 1/1] LED (ISL-305X302; CCS Inc., Kyoto, Japan) lights (Fig. 1). All seedlings were irradiated for $14 \mathrm{~h}$ at $100 \mu \mathrm{mol} \cdot \mathrm{m}^{-2} \cdot \mathrm{s}^{-1} P P F$. The wavelength of the light source was determined by a USB2000 spectrometer (Ocean Optics, Dunedin, FL) (Fig. 2).

At 17 DAS, the seedlings were transplanted to plastic pots (diameter, $60 \mathrm{~mm}$; depth, $70 \mathrm{~mm}$ ) filled with the same substrate and grown in a greenhouse maintained at $25 \pm$ $2{ }^{\circ} \mathrm{C}$ with a light period of $12 \mathrm{~h} \cdot \mathrm{d}^{-1}$; the main light source was sunlight supplemented with a FL (1600 to $1900 \mathrm{HR}$ ). The lettuce seedlings 
were supplied with a nutrient solution containing 9.2 nitrogen, 2.6 phosphorus, 4.4 potassium, 2.2 calcium, and 0.8 magnesium in $\mathrm{mmol} \cdot \mathrm{L}^{-1}$. Five or six seedlings were sampled at 10, 17, and 45 DAS, and their leaf number, leaf area, and FW were measured. Moreover, these samples frozen immediately by liquid nitrogen and dried with a freeze dry machine (Labconco Co., Kansas, MO). Dry matter weight (DMW) was also measured.

Chlorophyll content. Chl was eluted from the dry matter samples ( $5 \mathrm{mg}$ ) with $1 \mathrm{~mL} 80 \%$ acetone at $4{ }^{\circ} \mathrm{C}$ overnight and determined by the method of Lichtenthaler and Welburn (1983). The sample was then centrifuged at $15,000 \mathrm{~g}$ for 3 min (Tomy Co., Tokyo, Japan). The supernatant was applied to a 96-well plate, and the absorbance of the $\mathrm{Chl}$ in acetone was measured at wavelengths of 470, 645, and $663 \mathrm{~nm}$ with a 96-well Benchmark microplate reader (BioRad Laboratories, Richmond, CA).

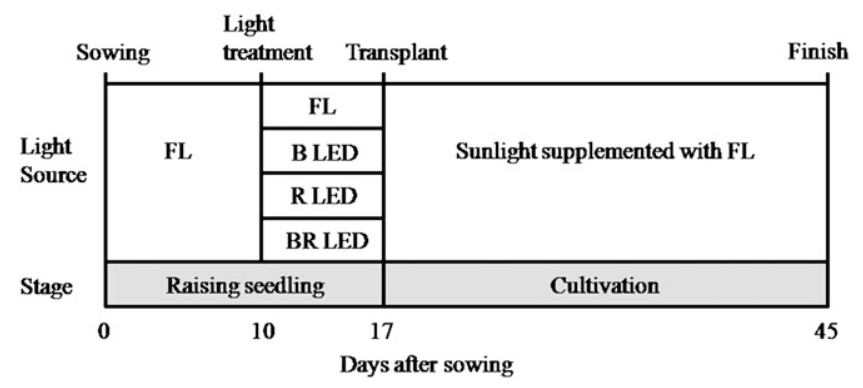

Fig. 1. Scheme of light treatment used when raising seedlings and their cultivation after the light treatment. The light period was $14 \mathrm{~h}$ under a white fluorescent lamp (FL) or blue (B), red (R), and blue + red (BR) light-emitting diode (LED) lights when raising seedlings and $12 \mathrm{~h}$ with sunlight supplemented with FL (1600 to 1900 HR) when cultivated in the greenhouse.
Phenol content. Anthocyanin was eluted from the dry matter samples $(5 \mathrm{mg})$ with 1 $\mathrm{mL}$ methanol and $1 \%$ hydrochloric acid at $4{ }^{\circ} \mathrm{C}$ overnight. The sample was then centrifuged at $15,000 \mathrm{~g}$ for $3 \mathrm{~min}$. The supernatant was applied to a 96-well plate and the absorbance of the anthocyanin was measured at a wavelength of $530 \mathrm{~nm}$ with the microplate reader.

Chlorogenic acid was eluted from the dry matter samples $(5 \mathrm{mg})$ with methanol at $4{ }^{\circ} \mathrm{C}$ overnight. The methanol extracts in the samples were filtered with a Millex-LG filter (Millipore Co., Billerica, MA), filled to $2 \mathrm{~mL}$ with methanol, and then the $100 \mu \mathrm{L}$ methanol extract was added to $900 \mu \mathrm{L}$ Buffer A (methanol:distilled water:formic acid = 70:426:4). Analysis of chlorogenic acid was performed using an ACUITY ultraperformance liquid chromatography (UPLC) system (Waters Co., Milford, MA) with a UPLC BEH

C18 column $(50 \times 2.1 \mathrm{~mm}, 1.7 \mu \mathrm{m}$; Waters Co., Milford, MA). The column oven was maintained at $40{ }^{\circ} \mathrm{C}$. The mobile phase consisted of buffer A and buffer B (methanol:distilled water $=65: 35$ ). The gradient program of buffer $\mathrm{B}$ was as follows: $0 \mathrm{~min}, 0 \%$; $0.5 \mathrm{~min}, 0 \%$; $2 \mathrm{~min}, 50 \%$; $2.5 \mathrm{~min}, 50 \%$; $3.5 \mathrm{~min}, 100 \%$; and $5.0 \mathrm{~min}, 0 \%$ at a flow rate of $0.7 \mathrm{~mL} \cdot \mathrm{min}^{-1}$. The detection wavelength was set at $310 \mathrm{~nm}$. Total phenol content in the methanol extracts was also determined by the method of Johkan et al. (2008).

Antioxidant activity. Antioxidants were eluted from the dry matter samples $(5 \mathrm{mg})$ with $1 \mathrm{~mL} 70 \%$ methanol at $4{ }^{\circ} \mathrm{C}$ overnight. The sample was centrifuged at $15,000 \mathrm{~g}$ for $3 \mathrm{~min}$. TAS was determined using a TAS kit (Randox Laboratories Ltd., Ardmore, U.K.), which is based on the presence of the radical cation ABTS $^{+}$[2,2-azionbis (3-ethylbenzothiazoline6-sulfonate)] produced by the ferrylmyoglobin radical generated from metmyoglobin and hydrogen peroxide. $\mathrm{ABTS}^{+}$absorbance was measured at a wavelength of $595 \mathrm{~nm}$ with a microplate reader.

Statistical analysis. Tukey's multiple range tests were used to test the difference between more than two means at the 0.05 significance level using the statistics software XLSTAT (Esmi Co., Tokyo, Japan).

\section{Results}

Plant growth. Lettuce seedlings treated with different light spectra showed different morphologies at 17 DAS (Fig. 3). Red light elongated the leaf blades of plants and bluecontaining LED lights dwarfed the seedlings

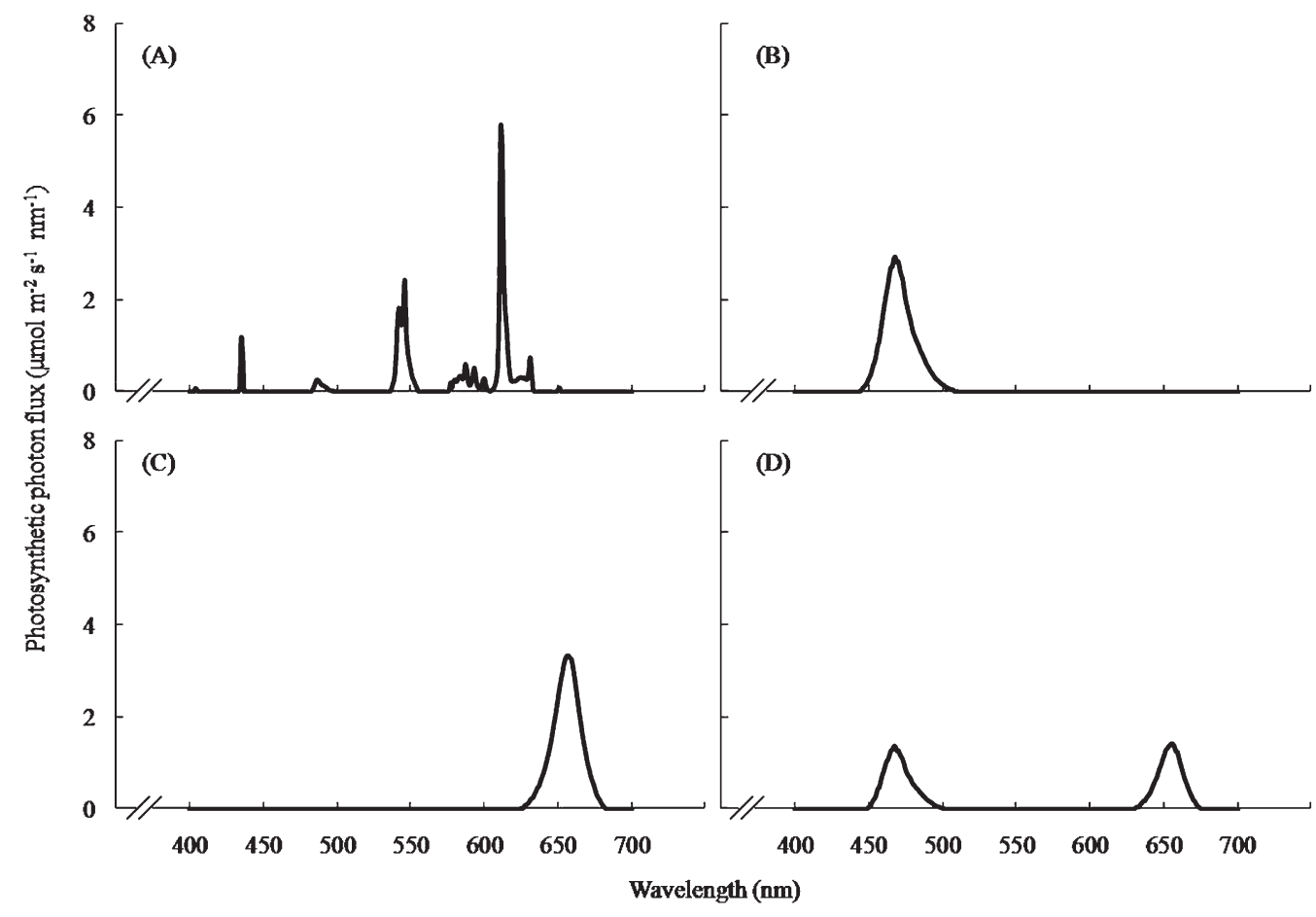

Fig. 2. Spectral photon flux distributions for the lighting treatments. (A) White fluorescent lamp; (B) blue light-emitting diode (LED) light; (C) red LED light; (D) blue + red LED light. Total photosynthetic photon flux $(P P F)$ was $100 \mu \mathrm{mol} \cdot \mathrm{m}^{-2} \cdot \mathrm{s}^{-1}$ for all lighting treatments. Spectral scans of LED lights were recorded at $20 \mathrm{~cm}$ below the panel of LEDs and that of FL was recorded at $45 \mathrm{~cm}$ below. 

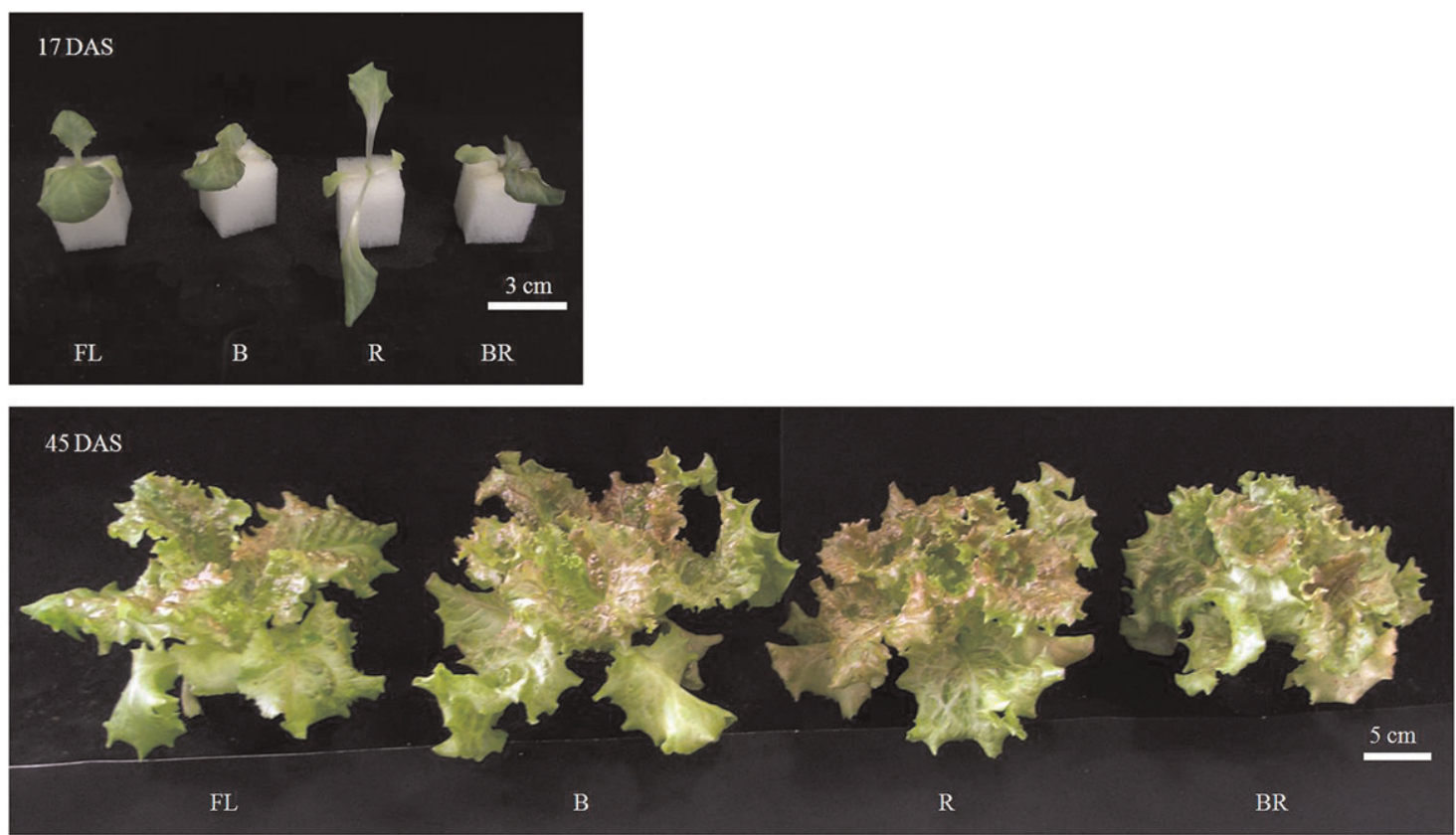

Fig. 3. Morphology of red leaf lettuce plants treated with a white fluorescent lamp (FL), blue (B), red (R), and blue + red (BR) light-emitting diode (LED) lights 17 (upper) and 45 (lower) days after sowing (DAS). Total photosynthetic photon flux $(P P F)$ was $100 \mu \mathrm{mol} \cdot \mathrm{m}^{-2} \cdot \mathrm{s}^{-1}$ for all lighting treatments.

Table 1. Effects of light spectrum on leaf number, leaf area, fresh weight, and dry weight in red leaf lettuce.

\begin{tabular}{llccccc}
\hline DAS $^{z}$ & \multicolumn{1}{c}{$\begin{array}{c}\text { Seaf } \\
\text { Sumbertrum }\end{array}$} & $\begin{array}{c}\text { Leaf area } \\
\left(\mathrm{cm}^{2}\right)\end{array}$ & $\begin{array}{c}\text { Fresh wt } \\
(\mathrm{mg})\end{array}$ & \multicolumn{2}{c}{ Dry matter wt $(\mathrm{mg} ; \mathrm{DMW})$} \\
\hline 17 & FL $^{\mathrm{x}}$ & $3 \mathrm{a}^{\mathrm{w}}$ & $27 \mathrm{~b}$ & $573 \mathrm{bc}$ & $27 \mathrm{~b}$ & $6 \mathrm{~b}$ \\
& Blue $(470 \mathrm{~nm})$ & $3 \mathrm{a}$ & $15 \mathrm{c}$ & $543 \mathrm{c}$ & $32 \mathrm{~b}$ & $11 \mathrm{ab}$ \\
& Red $(660 \mathrm{~nm})$ & $3 \mathrm{a}$ & $36 \mathrm{a}$ & $719 \mathrm{a}$ & $35 \mathrm{ab}$ & $8 \mathrm{ab}$ \\
& Blue + red $(470+660 \mathrm{~nm})$ & $3 \mathrm{a}$ & $25 \mathrm{~b}$ & $656 \mathrm{ab}$ & $45 \mathrm{a}$ & $14 \mathrm{a}$ \\
& & & & & & \\
45 & FL & $17 \mathrm{a}$ & $981 \mathrm{ab}$ & $30,895 \mathrm{~b}$ & $1,615 \mathrm{c}$ & $109 \mathrm{~b}$ \\
& Blue $(470 \mathrm{~nm})$ & $16 \mathrm{a}$ & $921 \mathrm{a}$ & $37,430 \mathrm{a}$ & $2,026 \mathrm{a}$ & $169 \mathrm{ab}$ \\
& Red $(660 \mathrm{~nm})$ & $17 \mathrm{a}$ & $1,080 \mathrm{ab}$ & $37,574 \mathrm{a}$ & $1,706 \mathrm{bc}$ & $178 \mathrm{a}$ \\
& Blue + red $(470+660 \mathrm{~nm})$ & $1,955 \mathrm{ab}$ & $189 \mathrm{a}$ \\
\hline
\end{tabular}

${ }^{2}$ Days after sowing. 17 DAS $=$ raising seedlings; 45 DAS $=$ final cultivation.

${ }^{\mathrm{y}}$ Photosynthetic photon flux $100 \pm 10 \mu \mathrm{mol} \cdot \mathrm{m}^{-2} \cdot \mathrm{s}^{-1}$.

${ }^{\mathrm{x}}$ White fluorescent lamp.

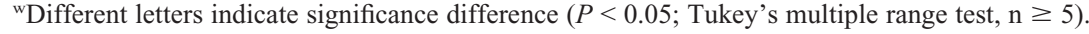

compared with FL. At 17 DAS, lettuce seedlings treated with blue-containing LED lights had reddish leaves, whereas the leaves of seedlings treated with red light were bright green. However, the leaves treated with red light mostly became red and developed normally like those under FL at 45 DAS.

No difference were observed in leaf number irrespective of the light spectrum, but leaf area, FW, and DMW were affected by the light spectrum (Table 1). At 17 DAS, the leaf area of plants treated with red light increased $33 \%$ compared with plants under FL, but that with blue-containing LED lights decreased greater than $9 \%$. The FW of lettuce seedlings treated with red light was the highest (719 $\mathrm{mg}$ ) of all the light spectra. In blue light, the FW of lettuce seedlings was less than that of seedlings under FL, but the shoot DMW increased by $29 \%$. The root DMW of lettuce seedlings treated with blue-containing LED lights increased greater than $83 \%$ compared with seedlings under FL. The shoot/root (S/ R) ratio and specific leaf area (SLA) under FL and red light were higher than under bluecontaining LED lights (Fig. 4).

The growth of lettuce plants raised with artificial light for 1 week and with sunlight for 4 weeks differed from that at 17 DAS (Table 1). Leaf areas of plants treated with blue-containing LED lights were greater than those under FL and red light. The FW of lettuce plants treated with blue-containing LED lights increased 21\% compared with those under FL and red light. The root dry weight (DW) under irradiation with blue + red light was the highest of all plant treatments, and the $\mathrm{S} / \mathrm{R}$ ratio was highest in lettuce seedlings treated with FL (Fig. 4). The SLA in lettuce plants under all light treatments were $\approx 0.56 \mathrm{~cm}^{2} \cdot \mathrm{mg}^{-1} \mathrm{DMW}$ at 45 DAS.

Chlorophyll content. The light spectrum affected the content of $\mathrm{Chl}$ in the leaves of lettuce seedlings (Table 2). At 17 DAS, the total Chl content was $9.0 \mu \mathrm{g} \cdot \mathrm{mg}^{-1} \mathrm{DMW}$. At 17 DAS, the total Chl content decreased from that at 10 DAS irrespective of the light spectrum. The total Chl content of seedlings treated with blue-containing LED lights (less than $8.2 \mu \mathrm{g} \cdot \mathrm{mg}^{-1} \mathrm{DMW}$ ) was lower than that with FL $\left(8.6 \mu \mathrm{g} \cdot \mathrm{mg}^{-1} \mathrm{DMW}\right)$ and was lowest with red light $\left(7.3 \mu \mathrm{g} \cdot \mathrm{mg}^{-1} \mathrm{DMW}\right)$. At 45 DAS, the total Chl content in lettuce leaves treated under all light conditions was 6.4 to $8.4 \mu \mathrm{g} \cdot \mathrm{mg}^{-1} \mathrm{DMW}$.

The Chl $a / b$ ratio in the leaves of lettuce seedlings treated with FL and red light at 17 DAS was 3.4, which was the same as at 10 DAS. However, the $\mathrm{Chl} a / b$ ratio under bluecontaining LED lights increased from the value of 3.4 for FL and red light to greater than 4.0. At $45 \mathrm{DAS}$, the $\mathrm{Chl} a / b$ ratio of seedlings treated with blue-containing LED lights decreased to 3.6 along with that for FL (3.7) and red light (3.5).

Carotenoid contents in the leaves of lettuce seedlings treated with blue-containing LED lights increased from $263 \mu \mathrm{g} \cdot \mathrm{mg}^{-1}$ DMW under FL to greater than $287 \mu \mathrm{g} \cdot \mathrm{mg}^{-1}$ DMW at 17 DAS. The contents in lettuce leaves treated with red light decreased from the value under FL to $231 \mu \mathrm{g} \cdot \mathrm{mg}^{-1} \mathrm{DMW}$. At 45 DAS, the carotenoid contents in lettuce leaves treated under all light conditions were 220 to $276 \mu \mathrm{g} \cdot \mathrm{mg}^{-1}$ DMW.

Phenol content. The total phenol content in lettuce seedlings at 17 DAS increased from that at 10 DAS, except for seedlings irradiated with red light (Table 3). At 17 DAS, the total phenol content was significantly higher in lettuce seedlings treated with bluecontaining LED lights (greater than 118.7 $\mathrm{nmol} \cdot \mathrm{mg}^{-1} \mathrm{DMW}$ ) than in seedlings treated with FL (75.7 nmol. $\left.\mathrm{mg}^{-1} \mathrm{DMW}\right)$ but was significantly lower in seedlings treated with red light (47.0 nmol. $\left.\mathrm{mg}^{-1} \mathrm{DMW}\right)$. However, the difference in total phenols content among the light treatments was diminished at 45 DAS. 


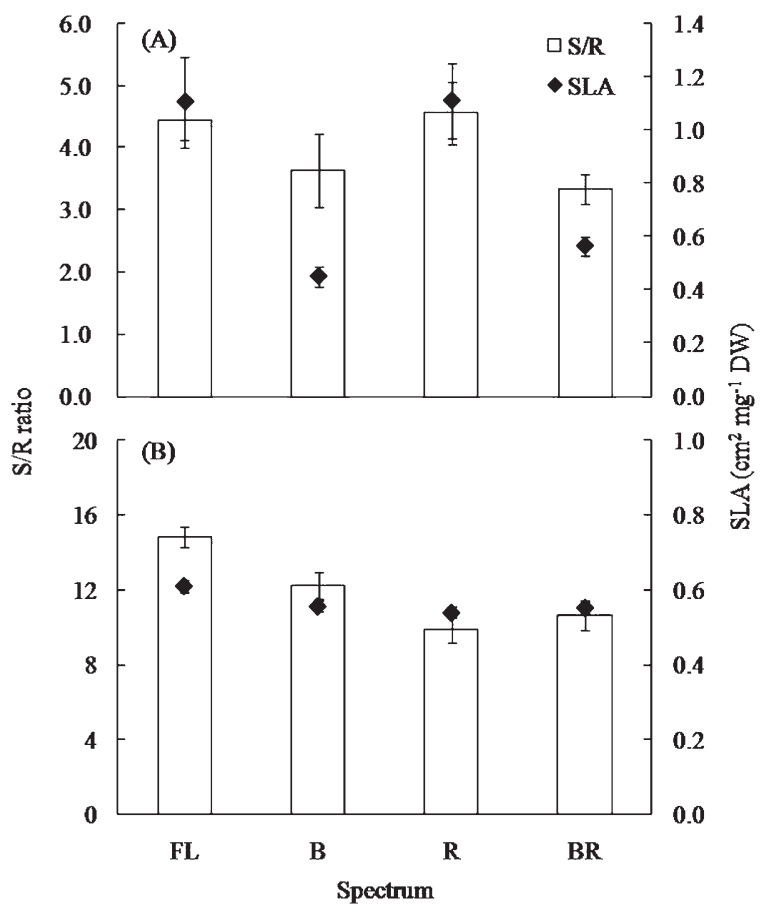

Fig. 4. Effects of light-emitting diode (LED) lights on shoot/root (S/R) ratio and specific leaf area (SLA) of the lettuce seedlings 17 (A) and 45 (B) day after sowing. $\mathrm{FL}=$ white fluorescent lamp; B = blue LED; $\mathrm{R}=$ red LED; $\mathrm{BR}=$ blue + red LEDs. Total photosynthetic photon flux $(P P F)$ was $100 \mu \mathrm{mol}^{-2} \cdot \mathrm{m}^{-2} \cdot \mathrm{s}^{-1}$ in all lighting treatments. Error bars represent $\mathrm{SE}(\mathrm{n} \geq 5)$.

Table 2. Effects of light-emitting diode lights on contents of chlorophyll a, b, $a / b$ ratio, and carotenoids in red leaf lettuce plants.

\begin{tabular}{llccc}
\hline DAS $^{z}$ & \multicolumn{1}{c}{ Spectrum $^{\mathrm{y}}$} & $\begin{array}{c}\text { Total Chl } \\
\left(\mu \mathrm{g} \cdot \mathrm{mg}^{-1} \mathrm{DMW}\right)\end{array}$ & Chl $\mathrm{a} / \mathrm{b}$ & $\begin{array}{c}\text { Carotenoids } \\
\left(\mu \mathrm{g} \cdot \mathrm{mg}^{-1} \mathrm{DMW}\right)\end{array}$ \\
\hline 10 & FL $^{\mathrm{x}}$ & 9.0 & 3.3 & 248 \\
& & & & \\
& FL & $8.6 \mathrm{a}^{\mathrm{w}}$ & $3.4 \mathrm{a}$ & $263 \mathrm{bc}$ \\
& Blue $(470 \mathrm{~nm})$ & $8.2 \mathrm{ab}$ & $4.1 \mathrm{~b}$ & $287 \mathrm{ab}$ \\
& Red $(660 \mathrm{~nm})$ & $7.3 \mathrm{c}$ & $3.4 \mathrm{a}$ & $231 \mathrm{c}$ \\
& Blue + red $(470+660 \mathrm{~nm})$ & $8.1 \mathrm{~b}$ & $4.0 \mathrm{~b}$ & $304 \mathrm{a}$ \\
& FL & $8.4 \mathrm{a}$ & $3.7 \mathrm{a}$ & $276 \mathrm{a}$ \\
& Blue $(470 \mathrm{~nm})$ & $6.7 \mathrm{a}$ & $3.6 \mathrm{a}$ & $228 \mathrm{a}$ \\
& Red $(660 \mathrm{~nm})$ & $7.3 \mathrm{a}$ & $3.5 \mathrm{a}$ & $247 \mathrm{a}$ \\
& Blue + red $(470+660 \mathrm{~nm})$ & $6.4 \mathrm{a}$ & $3.6 \mathrm{a}$ & $220 \mathrm{a}$ \\
\hline
\end{tabular}

${ }^{2}$ Days after sowing. $17 \mathrm{DAS}=$ raising seedlings; $45 \mathrm{DAS}=$ final cultivation.

yPhotosynthetic photon flux $100 \pm 10 \mu \mathrm{mol} \cdot \mathrm{m}^{-2} \cdot \mathrm{s}^{-1}$.

${ }^{x}$ White fluorescent lamp.

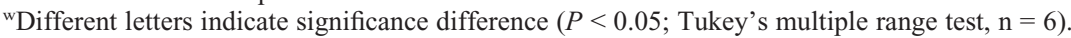

The contents of chlorogenic acid in lettuce seedlings at 17 DAS increased from that at 10 DAS. Chlorogenic acid in lettuce seedlings treated with blue-containing LED lights (greater than $32.4 \mathrm{nmol} \cdot \mathrm{mg}^{-1}$ DMW) was higher than that in lettuce seedlings treated with FL $\left(18.8 \mathrm{nmol} \cdot \mathrm{mg}^{-1}\right.$ DMW $)$ and red light $\left(16.8 \mathrm{nmol} \cdot \mathrm{mg}^{-1} \mathrm{DMW}\right)$. The contents of chlorogenic acid in seedlings treated with FL and red light at 45 DAS increased greater than $20.9 \mathrm{nmol} \cdot \mathrm{mg}^{-1} \mathrm{DMW}$ from 17 DAS but decreased greater than $28 \%$ with blue-containing LED lights.

Anthocyanin contents in lettuce seedlings treated with blue-containing LED lights at 17 DAS were greater than those in lettuce seedlings treated with FL at 10 DAS. The bluecontaining LED lights significantly increased the anthocyanin contents in lettuce seedlings and the contents in the case of blue + red light were the highest of all treatments. However, the anthocyanin contents in lettuce plants treated with blue + red light at 45 DAS decreased from values at 17 DAS. The anthocyanin contents in lettuce seedlings treated with red light at 17 DAS were significantly lower than contents in the case of FL, but the contents at 45 DAS increased twofold.

TAS activities in lettuce seedlings treated with FL and blue-containing LED lights at 17 DAS were higher than at 10 DAS but not for red light. TAS activities in lettuce seedlings treated with blue-containing LED lights (greater than $547 \mathrm{nmol} \cdot \mathrm{mg}^{-1} \mathrm{DW}$ ) at 17 DAS were significantly higher than those in lettuce seedlings treated with FL (greater than $332 \mathrm{nmol} \cdot \mathrm{mg}^{-1} \mathrm{DMW}$ ), but those at 45 DAS decreased to the same level as for lettuce plants treated with FL. However, the TAS activity in lettuce seedlings treated with red light at 17 DAS was significantly lower than that for FL but increased at 45 DAS.

\section{Discussion}

Irradiation with blue LED light suppressed the leaf growth of lettuce seedlings, but the DW of shoots and roots was greater than that of lettuce seedlings treated with FL at 17 DAS. At 45 DAS, the leaf area and FW, which are important elements of yield in leaf lettuce plants, were highest for lettuce plants treated with blue and blue + red LED lights. Blue LED light irradiation tends to increase biomass production (Hogewoning et al., 2010). Yorio et al. (2001) also reported that there was higher DMW accumulation in lettuce grown under red light supplemented with blue light than in lettuce grown under red light alone. However, shoot DMW of leaf lettuce plants irradiated with blue FL decreased compared with that of white FL, which included a $10 \%$ blue region (Ohashi-Kaneko et al., 2007). The blue FL used by Ohashi-Kaneko et al. (2007) included a $75 \%$ blue region and other regions in the spectra such as ultraviolet, far red, green, and red. The decrease of shoot DMW under blue FL may be caused by other regions of the spectrum under blue FL. Moreover, a broad spectrum of the blue region under blue FL (400 to $500 \mathrm{~nm}$ ) may indicate that some of the blue spectrum does not contribute to increases in biomass production.

Successful transplantation and promoted early growth after transplant requires vigorous seedling roots. The $\mathrm{S} / \mathrm{R}$ ratio of lettuce seedlings treated with blue-containing LED lights at 17 DAS was lower than that of lettuce seedlings treated with FL and red light, and the FW of lettuce plants treated with blue-containing LED lights at 45 DAS was greater than $29 \%$ greater than that of lettuce plants treated with FL and red light. Vigorous roots support shoot growth by fully supplying the plant with water and mineral nutrition. In contrast, sprouting seedlings in which stems rapidly elongate under low irradiation or excess water have small roots that do not receive sufficient water or mineral nutrients, which decreases plant growth. Poor roots cannot supply sufficient water for large shoots, so plants with high $\mathrm{S} / \mathrm{R}$ ratios are unsuitable for active growth. In the bluecontaining LED light treatment, lettuce seedlings had low SLAs, and the leaves turned toward the light source. The seedlings treated with red light had the largest leaf area, but the leaves turned away from the light source. Therefore, seedlings treated with red light might have a disadvantage in photosynthetic morphology (Hogewoning et al., 2010).

Chls are greenish pigments that absorb blue and red light, and Chl $a$ is the molecule that makes photosynthesis possible. This is achieved by passing energized electrons to molecules that manufacture sugars. In this study, the total Chl content in lettuce seedlings 
Table 3. Effects of light-emitting giode lights on contents of phenols, anthocyanin, chlorogenic acid, and TAS in red leaf lettuce plants.

\begin{tabular}{|c|c|c|c|c|c|}
\hline $\mathrm{DAS}^{\mathrm{z}}$ & Spectrum $^{y}$ & $\begin{array}{c}\text { Total phenols } \\
\text { (nmol.mg } \\
\text { DMW) }\end{array}$ & $\begin{array}{l}\text { Chlorogenic acid } \\
\left(\mathrm{nmol} \cdot \mathrm{mg}^{-1}\right. \\
\text { DMW })\end{array}$ & $\begin{array}{c}\text { Anthocyanin } \\
\text { (OD530 mg } \\
\text { DMW) }\end{array}$ & $\begin{array}{c}\mathrm{TAS}^{\mathrm{w}} \\
\left(\mathrm{nmol} \cdot \mathrm{mg}^{-1}\right. \\
\mathrm{DMW})\end{array}$ \\
\hline$\overline{10}$ & $\mathrm{FL}^{\mathrm{v}}$ & 55.4 & 2.5 & 0.07 & 278 \\
\hline \multirow[t]{4}{*}{17} & FL & $75.7 \mathrm{c}^{\mathrm{u}}$ & $6.2 \mathrm{~b}$ & $0.08 \mathrm{c}$ & $332 \mathrm{c}$ \\
\hline & Blue $(470 \mathrm{~nm})$ & $118.7 \mathrm{~b}$ & $15.0 \mathrm{a}$ & $0.15 \mathrm{~b}$ & $547 \mathrm{~b}$ \\
\hline & $\operatorname{Red}(660 \mathrm{~nm})$ & $47.0 \mathrm{~d}$ & $1.9 \mathrm{c}$ & $0.06 \mathrm{~d}$ & $194 \mathrm{~d}$ \\
\hline & $\begin{array}{l}\text { Blue + red } \\
\qquad(470+660 \mathrm{~nm})\end{array}$ & $161.6 \mathrm{a}$ & $14.7 \mathrm{a}$ & $0.27 \mathrm{a}$ & $749 \mathrm{a}$ \\
\hline \multirow[t]{4}{*}{45} & FL & $138.8 \mathrm{a}$ & $8.1 \mathrm{a}$ & $0.11 \mathrm{a}$ & $376 \mathrm{a}$ \\
\hline & Blue $(470 \mathrm{~nm})$ & $126.8 \mathrm{a}$ & $6.7 \mathrm{a}$ & $0.14 \mathrm{a}$ & $424 \mathrm{a}$ \\
\hline & $\operatorname{Red}(660 \mathrm{~nm})$ & $139.9 \mathrm{a}$ & $8.7 \mathrm{a}$ & $0.12 \mathrm{a}$ & $421 \mathrm{a}$ \\
\hline & $\begin{array}{l}\text { Blue + red } \\
\quad(470+660 \mathrm{~nm})\end{array}$ & $138.3 \mathrm{a}$ & $9.1 \mathrm{a}$ & $0.13 \mathrm{a}$ & $481 \mathrm{a}$ \\
\hline
\end{tabular}

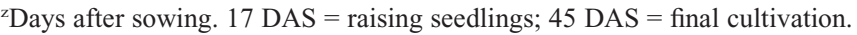

y Photosynthetic photon flux $100 \pm 10 \mu \mathrm{mol} \cdot \mathrm{m}^{-2} \cdot \mathrm{s}^{-1}$.

${ }^{x}$ Chlorogenic acid equivalent.

wTotal antioxidant system, Trolox equivalent.

${ }^{\mathrm{v}}$ White fluorescent lamp.

"Different letters indicate significance difference $(P<0.05$; Tukey's multiple range test, $\mathrm{n}=6)$.

treated with FL and red light was higher than that in lettuce seedlings treated with bluecontaining light; however, the $\mathrm{Chl} a / b$ ratio increased under blue-containing LED lights. Blue light could be more effective than red light in the induction of $\mathrm{Chl}$ synthesis in primary barley leaves (Bukhov et al., 1992), and the Chl $a / b$ ratio usually increases with increasing irradiance in a plant's growth environment (Evans and Poorter, 2001). Moreover, the content of carotenoid, the most important functions of which include the dissipation of excess energy of excited $\mathrm{Chl}$ and the elimination of reactive oxygen species (Schagerl and Muller, 2006), increased under the bluecontaining LED lights treatment. We suggest that a higher $\mathrm{Chl} a / b$ ratio and carotenoids in seedlings treated with blue-containing LED lights would have an advantage in light absorption and may therefore have improved photosynthesis after transplantation.

Seedlings treated with blue-containing LED lights had high contents of polyphenols such as anthocyanin and chlorogenic acid. Polyphenols are thought to be phytochemicals that protect plants that cannot move when the environment changes unsuitably (Pizzi and Cameron, 1986; Ryan et al., 2002; Tattini et al., 2004). The spectrum of blue light near the ultraviolet region may induce similar responses to environmental signals for ultraviolet, which induce polyphenol synthesis (Ebisawa et al., 2008; Ryan et al., 2002). The antioxidant activities of seedlings treated with blue-containing LED lights were higher than that under FL and red light. High correlations between antioxidant activity and total phenol content were the same as in previous studies (Bahorun et al., 2004; Gardner et al., 2000), and anthocyanin and chlorogenic acid also had high correlations with antioxidant activity (data not shown). However, the higher polyphenol contents and antioxidant activity of seedlings treated with blue-containing LED lights diminished at 45 DAS. These results indicated that the polyphenol contents and antioxidant activity in the plants adjusted to the environment after transplanting, and the characteristics developed in seedlings may be lost unless treatment with a higher rate ( $50 \%$ or greater) of blue light in the light source is continued after transplanting.

Plant growth is seriously suppressed by environmental stress. In tomato plants, the DW per plant under thermal stress $\left(35^{\circ} \mathrm{C}\right)$ was $68 \%$ less than that under optimal conditions $\left(25^{\circ} \mathrm{C}\right)$ (Rivero et al., 2003). Drought or salinity stress also decreases plant growth compared with that of unstressed plants (Alexieva et al., 2001). The decrease in plant growth under environmental stress might be attributed to the overproduction of reactive oxygen species (Moran et al., 1994). Indeed, plants with environmental stress tolerance had higher antioxidant activity under stress conditions compared with plants without tolerance (Kasuga et al., 1999; Roxas et al., 2000). These reports might indicate that plant seedlings with high antioxidant activity had a high tolerance for environmental stress. The high antioxidant activity in seedlings induced by irradiance with blue light was similar to the grafting of a rootstock to a scion that could transfer environmental tolerance. Therefore, the increase in yield in lettuce plants may be caused by high antioxidant activity in seedlings treated with blue-containing LED lights.

In conclusion, our results indicate that raising seedlings under blue light is useful in promoting the growth of lettuce plants after transplanting because of the advantageous morphology for photosynthesis and the high antioxidant activity in the lettuce seedlings. The compact morphology with vigor roots of lettuce seedlings treated with blue light would be also useful for transplanting.

\section{Literature Cited}

Alexieva, V., I. Sergiev, S. Mapelli, and E. Karanov. 2001. The effect of drought and ultraviolet radiation on growth and stress markers in pea and wheat. Plant Cell Environ. 24:1337-1344.

Awada, M.A., P.S. Wagenmakersb, and A.D. Jager. 2001. Effects of light on flavonoid and chlorogenic acid levels in the skin of 'Jonagold' apples. Sci. Hort. 88:289-298.

Bahorun, T., A. Luximon-Ramma, A. Crozier, and O.I. Aruoma. 2004. Total phenol, flavonoid, proanthocyanidin and vitamin $\mathrm{C}$ levels and antioxidant activities of Mauritian vegetables. J. Sci. Food Agr. 84:1553-1561.

Bukhov, N.G., I.S. Drozdova, V.V. Bondar, and A.T. Mokronosov. 1992. Blue, red and blue plus red light control of chlorophyll content and $\mathrm{CO}_{2}$ gas exchange in barley leaves: Quantitative description of the effects of light quality and fluence rate. Physiol. Plant. 85:632-638.

Duan, X.W., Y.M. Jiang, X.G. Su, Z.Q. Zhang, and J. Shi. 2007. Antioxidant property of anthocyanins extracted from litchi (Litchi chinenesis Sonn.) fruit pericarp tissues in relation to their role in the pericarp browning. Food Chem. 101: 1382-1388

Ebisawa, M., K. Shoji, M. Kato, K. Shimomura, F. Goto, and T. Yoshihara. 2008. Supplementary ultraviolet radiation $\mathrm{B}$ together with blue light at night increased quercetin content and flavonol synthase gene expression in leaf lettuce (Lactuca sativa L.). Environ. Control Biol. 46: $1-11$.

Evans, J.R. and H. Poorter. 2001. Photosynthetic acclimation of plants to growth irradiance: The relative importance of specific leaf area and nitrogen partitioning in maximizing carbon gain. Plant Cell Environ. 24:755-767.

Gardner, P.T., T.A.C. White, D.B. McPhail, and G.G. Duthie. 2000. The relative contributions of vitamin $\mathrm{C}$, carotenoids and phenolics to the antioxidant potential of fruit juices. Food Chem. 68:471-474

Hanyu, H. and K. Shoji. 2002. Acceleration of growth in spinach by short-term exposure to red and blue light at the beginning and at the end of the daily dark period. Acta Hort. 580:145-150.

Hogewoning, S.W., G. Trouwborst, H. Maljaars, H. Poorter, W. van-Ieperen, and J. Harbinson. 2010. Blue light dose-responses of leaf photosynthesis, morphology, and chemical composition of Cucumis sativus grown under different combinations of red and blue light. J. Expt. Bot. 6:3107-3117.

Johkan, M., G. Mori, K. Mitsukuri, K. Mishiba, T. Morikawa, and M. Oda. 2008. In vivo shoot regeneration promoted by shading the cut surfaces of the stem in tomato plants. HortScience 43:1-4.

Kasuga, M., Q. Liu, S. Miura, K. YamaguchiShinozaki, and K. Shinozaki. 1999. Improving plant drought, salt, and freezing tolerance by gene transfer of a single stress-inducible transcription factor. Nat. Biotechnol. 17:287291.

Kojima, M., Y. Nakano, and H. Fujii. 2010. Light stimulation triggered expression of genes coding for vacuolar proton-pump enzymes V-ATPase and V-PPase in buckwheat. Biosci. Biotechnol. Biochem. 74:1507-1511.

Lichtenthaler, H.K. and A.R. Welburn. 1983. Determinations of total carotenoids and chlorophyll $a$ and $b$ of leaf extracts in different solvents. Biochem. Soc. Trans. 11:591-593.

Matsuda, R., K. Ohashi-Kaneko, K. Fujiwara, and K. Kurata. 2008. Effects of blue light deficiency on acclimation of light energy partitioning in PSII and $\mathrm{CO}_{2}$ assimilation capacity to high irradiance in spinach leaves. Plant Cell Physiol. 49:664-670.

McNellis, T.W. and X.W. Deng. 1995. Light control of seedling morphogenetic pattern. Plant Cell 7:1749-1761.

Moran, J.F., M. Becana, I. Iturbe-Ormaetxe, S Frechilla, R.V. Klucas, and P. Aparicio-Tejo. 
1994. Drought induces oxidative stress in pea plants. Planta 194:346-352.

Oda, M. 2007. Raising of vigorous and valuable seedlings. Regul. Plant Grow. Develop. 42:176182 (in Japanese).

Ohashi-Kaneko, K., M. Takase, N. Kon, K. Fujiwara, and K. Kurata. 2007. Effect of light quality on growth and vegetable quality in leaf lettuce, spinach and komatsuna. Environ. Control Biol. 45:189-198.

Pizzi, A. and F.A. Cameron. 1986. Flavonoid tannins-Structural wood components for drought-resistant mechanisms of plants. Wood Sci. Technol. 20:119-124.

Rice-Evans, A.C., N.J. Miller, and G. Paganga. 1997. Antioxidant properties of phenolic compounds. New Trends Plant Sci. Rev. 2:152159.
Rivero, R.M., J.M. Ruiz, and L. Romero. 2003. Can grafting in tomato plants strengthen resistance to thermal stress? J. Sci. Food Agr. 83:13151319.

Roxas, V.P., S.A. Lodhi, D.K. Garrett, J.R. Mahan, and R.D. Allen. 2000. Stress tolerance in transgenic tobacco seedlings that overexpress glutathione S-transferase/glutathione peroxidase. Plant Cell Physiol. 41:1229-1234.

Ryan, K.G., E.E. Swinny, K.R. Markham, and C. Winefield. 2002. Flavonoid gene expression and UV photoprotection in transgenic and mutant Petunia leaves. Phytochemistry 59:2332.

Schagerl, M. and B. Muller. 2006. Acclimation of chlorophyll a and carotenoid levels to different irradiance in four freshwater cyanobacteria. J. Plant Physiol. 163:709-716.
Seiler, J.R. and J.D. Johnson. 1988. Physiological and morphological responses of three half-sib families of loblolly pine to water-stress conditioning. For. Sci. 34:487-495.

Tattini, M., C. Galardi, P. Pinelli, R. Massai, D. Remorini, and G. Agati. 2004. Differential accumulation of flavonoids and hydroxycinnamates in leaves of Ligustrum vulgare under excess light and drought stress. New Phytol. 163: 547-561.

Whitelam, G. and K. Halliday. 2007. Light and plant development. Blackwell Publishing, Oxford, UK.

Yorio, N.C., G.D. Goins, H.R. Kagie, R.M. Wheeler, and J.C. Sager. 2001. Improving spinach, radish, and lettuce growth under red light-emitting diodes (LEDs) with blue light supplementation. HortScience 36:380-383. 